\title{
Transtensional tectonism and its effects on the distribution of sandbodies in the Paleogene Baiyun Sag, Pearl River Mouth Basin, China
}

\author{
Jiahao Wang $\cdot$ Xiong Pang $\cdot$ Daqing Tang • \\ Baojun Liu $\cdot$ Donghao Xu
}

Received: 11 January 2013/Accepted: 29 September 2013/Published online: 17 October 2013

(C) The Author(s) 2013. This article is published with open access at Springerlink.com

\begin{abstract}
The Baiyun Sag, situated at the north continental slope of the South China Sea, is a main sub-unit in the Southern Depression Belt of the Pearl River Mouth Basin. In this Sag, the middle Eocene Wenchang and upper Eocenelower Oligocene Enping Formations had developed in the evolution stage of continental faulted basin. Seismic stratigraphic sequences and fault structures revealed that the Baiyun Sag was short of long-reaching boundary faults, and that it was a rifted basin greatly influenced by basement faults rather than a typical half-graben. Different from the sags in Northern Depression Belt of the Pearl River Mouth Basin which controlled by large-scale NEE-strike faults, the Baiyun Sag had been controlled by two groups of NWWstrike en echelon fault belts with approximate opposite dips, which developed in the southwest and northeast of this Sag respectively and had played the roles of boundary faults. These en echelon faults, together with narrow synclines, partial flower structures and fluid diapirs, indicated the leftlateral transtensional activities, which had resulted in subsidence center departing to main faults and stretching S-shaped. Moreover, the en echelon faults had constructed many composite transfer zones of relay ramps, and controlled the distribution of sandbodies. The en echelon fault
\end{abstract}

\footnotetext{
J. Wang $(\bowtie)$

Key Laboratory of Tectonics and Petroleum Resources, Ministry of Education, China University of Geosciences, Wuhan 430074, China

e-mail: cugwangjiahao@163.com

J. Wang · D. Tang · D. Xu

Faculty of Earth Resources, China University of Geosciences,

Wuhan 430074, Hubei, China

X. Pang $\cdot$ B. Liu

Institute CNOOC Ltd., Shenzhen, Guangzhou 510240, China
}

belts are located in accordance with Nw-striking Mesozoic basement faults. Hence the left-lateral transtensional activities were responsible for the Western Pacific Plate subducting and strike slip reactivation of the basement faults. Significantly, NW-striking basement faults had forcefully determined the development of not only the Baiyun Sag but also the Xingning Sag.

Keywords South China Sea - Pearl River Mouth Basin · Baiyun Sag · Paleogene · Transtension

\section{Introduction}

The Baiyun Sag is situated at the northern continental slope of the South China Sea with water-depth from 300 to $4,000 \mathrm{~m}$, and area of approximately $20,000 \mathrm{~km}^{2}$. With the discoveries of large-scale Neogene submarine fans at the beginning of twenty-first century, the Baiyun Sag became a hotspot of deep-water oil and gas exploration (Pang et al. 2004, 2005; Peng et al. 2004, 2005). The Baiyun Sag evolved from continental rift to passive continental marginal basin since the Late Cretaceous (Liu et al. 2011). The deep-seated middle Eocene Wenchang Formation and upper Eocene-lower Oligocene Enping Formation was deposited in the rifting stage. Both of them possessed good hydrocarbon source rocks with sedimentary facies of deep lacustrine, and had supplied abundant resources for the oil and gas accumulation of the Neogene submarine fan, which have been verified by recent petroleum discoveries (Chen et al. 2006; Pang et al. 2006).

In recent years, benefited from the improved 3D seismic data, many large-scale deposits with progradational reflection configuration on seismic profiles were identified as sedimentary facies of delta and fan delta in the 
Fig. 1 The Paleogene tectonic units of the Pearl river Mouth basin (adapted after Pang et al. 2005). I Panyu Low Uplift, II Yunkai Low Uplift, III Dongsha Uplift, IV Baiyun Sag,

$V$ Huizhou Sag, VI Xingning Sag, 1 city, 2 boundary of Pearl River Mouth Basin, 3 boundary of first-order tectonic unit, 4 boundary of second-order tectonic unit, $5 \mathrm{NW}$-strike fault

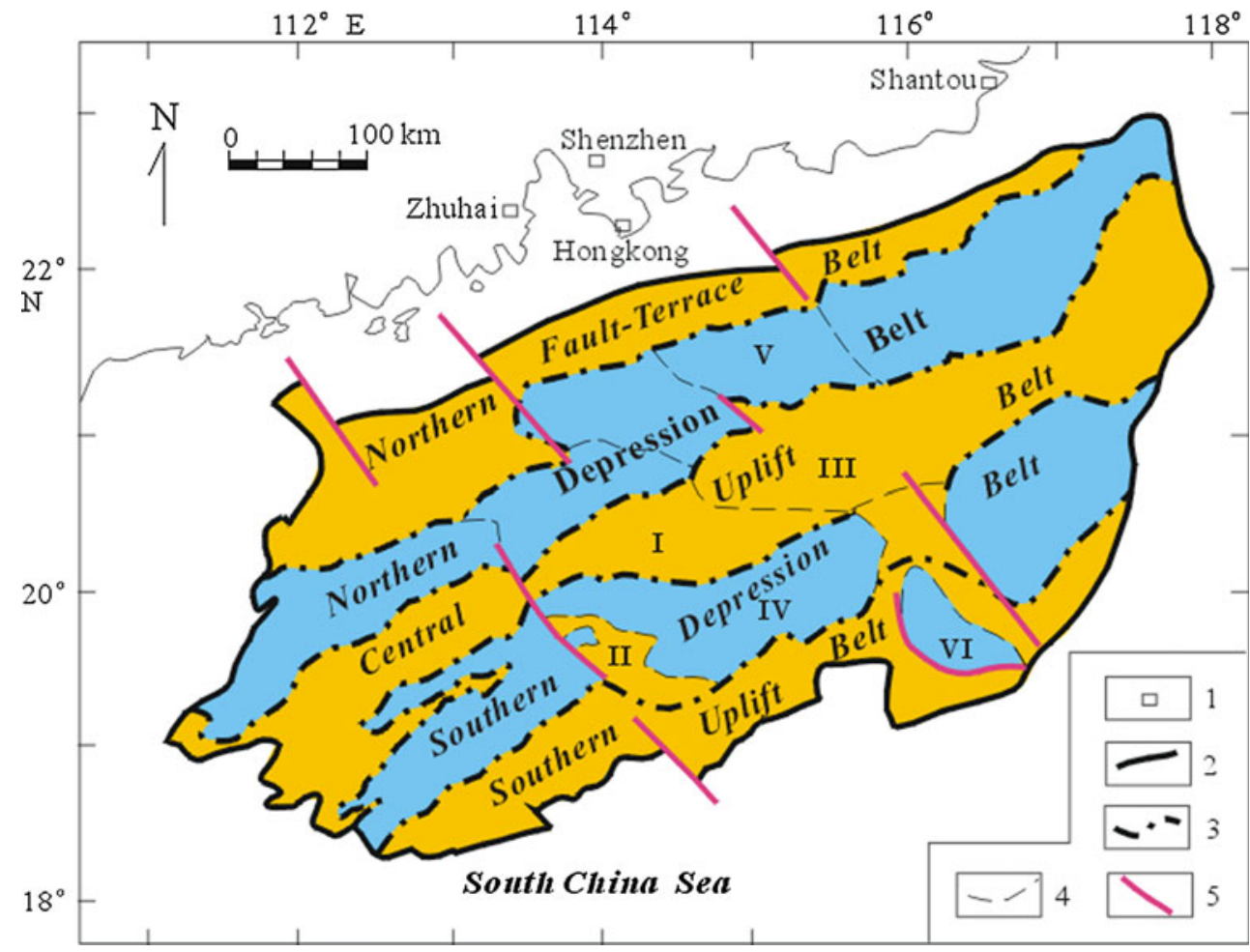

Wenchang and Enping Formations. Some of them broadly distributed with buried-depth $<3,000 \mathrm{~m}$ which were regarded as potential exploration targets.

Therefore, the intensified researches on tectonic activities and sedimentary filling in the development of Wenchang and Enping Formations are very useful for revealing the primary evolution of the passive continental slope of the South China Sea and for finding the favorable deep-seated targets.

\section{Geological background}

Controlled by two groups of faults with NEE and NW strike respectively, the Pearl River Mouth Basin presents a segmental and zonal structural framework in the NEE direction and in the NW direction respectively. This basin is divided into five structural units of the Northern FaultLadder Belt, Northern Depression Zone, Central Uplift Belt, Southern Depression Zone and Southern Uplift Belt. The Baiyun Sag located near the Panyu Low Uplift, the Dongsha Uplift and the Yunkai Low Uplift is a sub-unit of the Southern Depression Zone (Fig. 1).

The maximum thickness of the Wenchang and Enping Formations in the Baiyun Sag is up to $4,700 \mathrm{~m}$. Wenchang and Enping formations corresponded to reflection units between major unconformities Tg (49 Ma)-T80 (36 Ma), T80-T70 (30 Ma) respectively on seismic profiles. Six third-order sequence interfaces were further identified as T84-T81, T72 and T71, which divide the Wenchang
Formation into five third-order sequences and the Enping Formation into three-third-order sequences (illustrated in following Figs. 4, 5, 6, 7, 11, 12). To date, the Wenchang and Enping Formations hadn't completely been revealed although more than 10 wells had been drilled in this area, hence the lithologic and sedimentary data were mainly acquired by seismic facies analysis.

The overlying upper Oligocene Zhuhai Formation (23.8-30 Ma) above T70 was deposited with large-scale delta facies (Liu et al. 2011), while the Pearl River Mouth Basin evolved into down-warped basin. During this period, most faults waned to be stagnant, and the whole area subsided including uplifts, such as the Panyu Low Uplift and the Yunkai Low Uplift, etc., which had resulted in widespread transgression in the whole Pearl River Mouth Basin.

For a long time, due to the great depth of these strata and poor quality of 2D seismic data, the structural pattern of the Paleogene Baiyun Sag hadn't been confirmed. After analyzing structural frameworks on seismic profiles and simulating basin evolution, Sun et al. (2005) predicted that the Baiyun Sag was a wide graben in view of small ratio of length over width in plane and fairly small vertical displacement of main normal faults. The subsiding center departing to main faults with plenty magma intruded. They also speculated that the Baiyun Sag had developed on a hot and soft basement so as to be plastically deformed. Based on deep crustal structure analysis using seismic profile, Huang et al. (2005) brought forward that the Baiyun Sag had developed above the Mesozoic forearc basin. Based on the gravitational and 


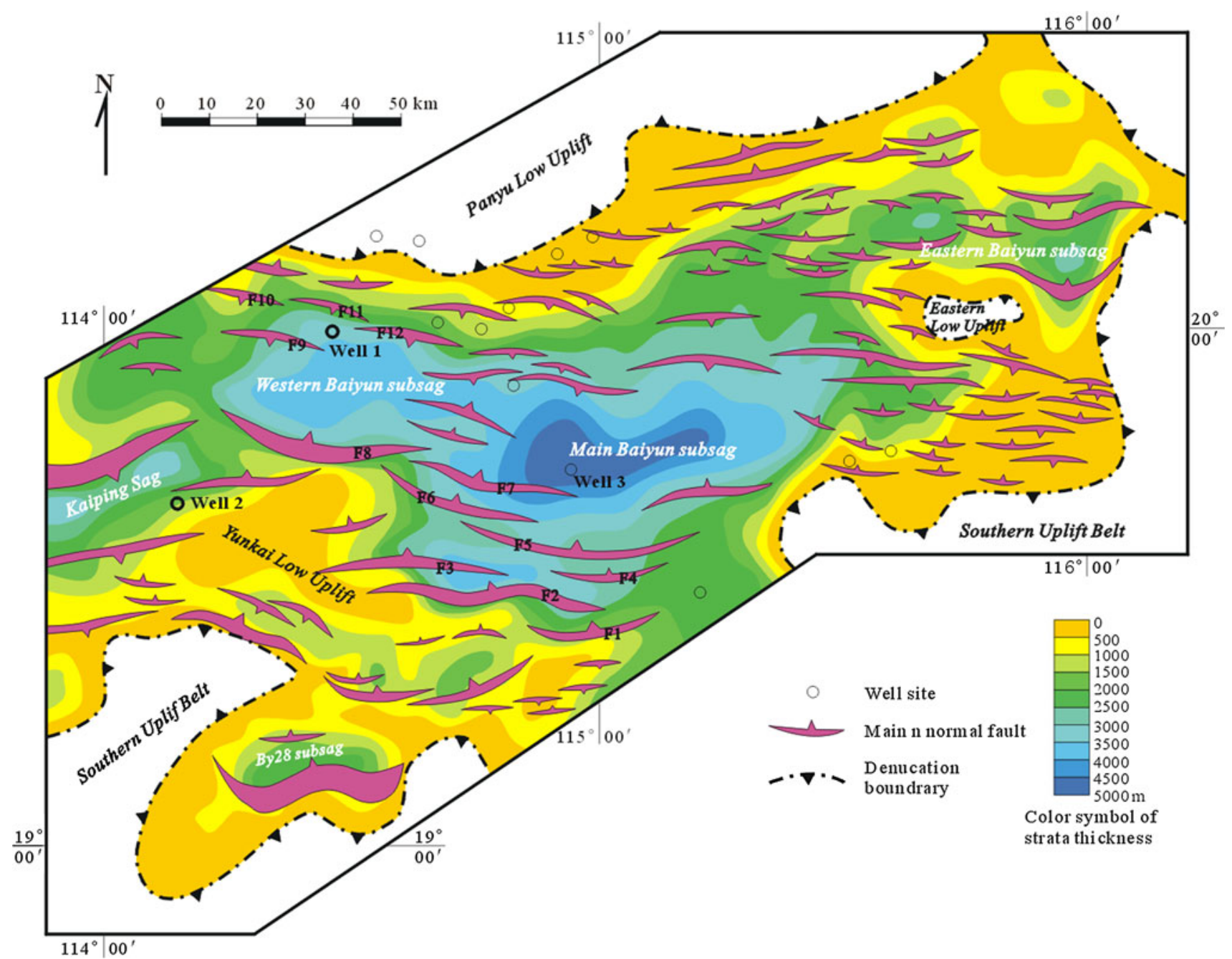

Fig. 2 Isopach map of the Wenchang-Enping formation overstacked by main normal faults in the Baiyun Sag

magnetic data and the faults distribution, Chen et al. (2005) and Zhou et al. (2006) concluded that the Pearl River Mouth Basin was located to the north of the Mesozoic Western Pacific Plate subduction zone, and that the regional stress field vitally transformed from left-lateral transpression to right-lateral transtension in the Late Cretaceous.

Based on comprehensive interpretation of seismic stratigraphic sequences and faults, this paper indicated that the middle Eocene to early Oligocene Baiyun Sag was formed under the stress field of left-lateral transtension rather than that of simple extension, and that abundant en echelon faults had constructed a lot of transfer zones of relay ramps to remarkably control sandbodies distributions.

\section{Left-lateral transtensional tectonic features}

The Baiyun Sag was composed of the Western Baiyun Subsag, Main Baiyun Subsag and Eastern Baiyun Subsag
(Fig. 2). As a whole, many main faults with fairly large displacement had developed in the southwestern Baiyun Sag. A wide gentle slope was shown by the strata gradually overlapping northwards in the northern Main Baiyun Sag. Hence the Baiyun Sag had even been taken as a half-graben.

As well known, a half-graben is controlled by one or several boundary faults under pure extensional tectonism. It presents an asymmetric structural pattern with the subsiding center adjacent to the boundary fault, and stretches parallel to the strike of boundary fault, such as the small-scale By28 subsag in the southwest of the study area (Figs. 2, 3).

However, from middle Eocene to early Oligocene, Baiyun Sag was different from typical half-graben in main fault distributions and position of subsiding center. Abundant en echelon faults, together with a few narrow synclines, diapirs and partial flower structures indicated that transtensional tectonism had played important roles in the development of the Baiyun Sag. 


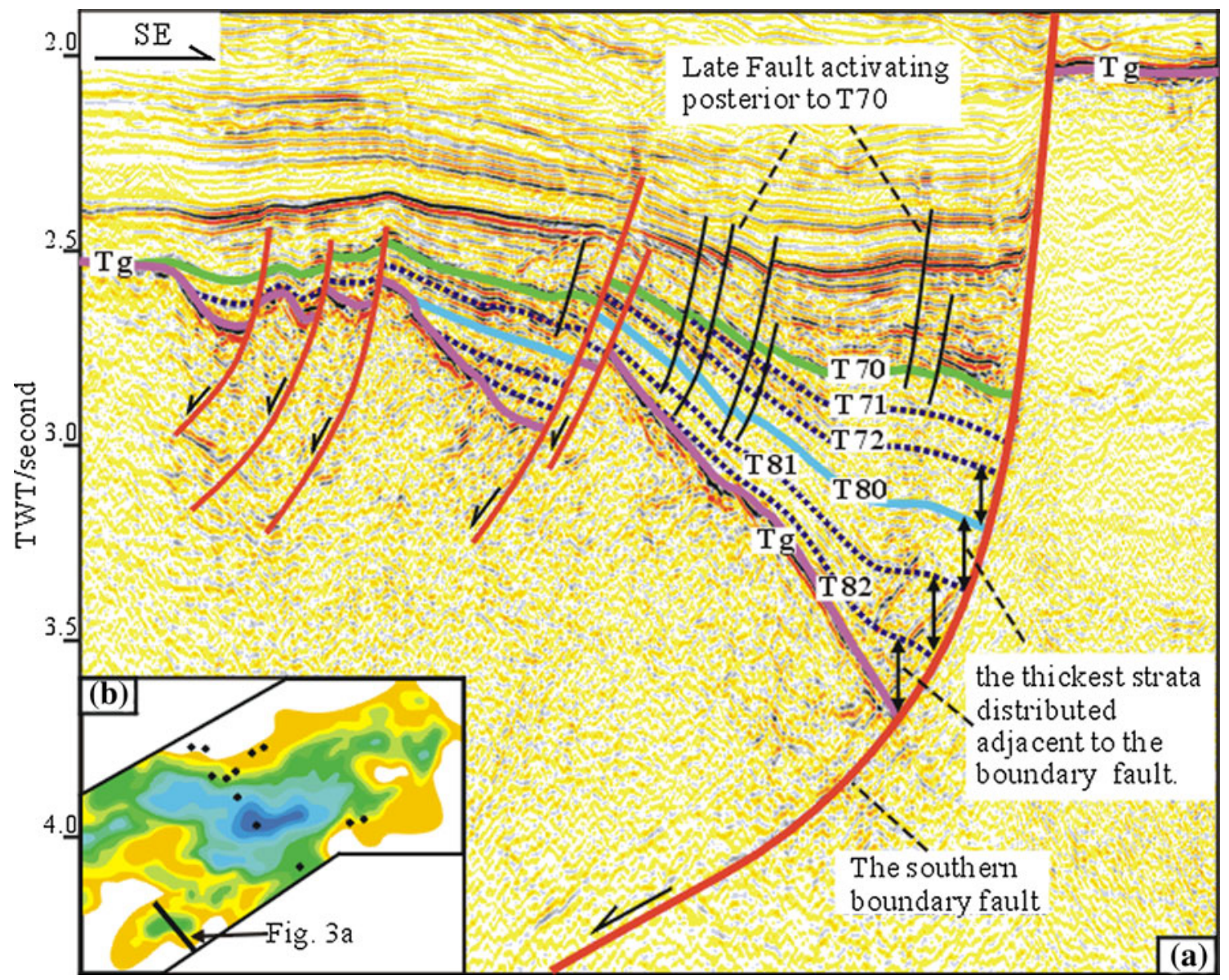

Fig. 3 The half-graben structural pattern of the By28 subsag. This subsag developed on the Southern Uplift Belt, and stretched paralleous to the southern boundary fault with thickest strata adjacent

En echelon faults

From middle Eocene to early Oligocene, the main faults in Baiyun Sag were dominantly characterized by NWWtrending, short curved or sigmoidal in plan view although some of them bear large vertical displacements. These were obviously different from NEE-trending, long-reaching main faults in the Northern Depression Zone such as the Huizhou Sag (Yu et al. 2009). Three to five faults commonly displayed en echelon arrangements especially in the southwest and northeast of Baiyun Sag (Fig. 2).

In the southwest, normal faults have larger dip angles and resulted in bigger total basement subsidence of about $4,000 \mathrm{~m}$. Twelve main faults constructed three en echelon fault belts. Two of the fault belts were composed respectively of F1-F3 and F4-F8 with NNE-dip; the third was composed of F9-F12 with SSW-dip (Figs. 2, 4). Consequently, the western Baiyun Sag presented the structural pattern of complex graben. Figure 4 shows that F5 was the southern boundary fault in the period of T84-Tg, F2 was the boundary fault in the period of T83-T84, and F1 was the boundary fault to the main fault. The NEE strike of the boundary fault is vertical to direction of regional extensional action (see $\mathbf{b}$ for the location of seismic profile)

in the period of T82-T83 while F10 still was the northern boundary fault. Therefore, accompanied with boundary fault shifting, the western Baiyun Sag expanded southward step by step in the development of the Wenchang Formation.

In the northeast, the active normal faults are less intensive than those in the southwest. About fourteen main faults with about 2,000 m total vertical displacement were identified. These Faults dipped toward SSW or NNE, and divided the eastern Main Baiyun Subsag into five mini-sags (Fig. 5). Specially, the southern mini-sags presented a graben pattern, which was constructed by eight faults with opposite dips. As a whole, in the northeastern Baiyun Sag, faults were denser, smaller in displacement and shorter in stretching distance than those in the western Baiyun Sag. Similarly, these faults displayed en echelon arrangement in plane (Fig. 2). Moreover, in the southern mini-sags, the Enping Formation was absent (Figs. 5, 6a-d), which suggested that boundary faults shifted northward.

To sum up, different structural patterns appeared in the different segment of the Baiyun Sag. The Western Baiyun Sag presented a structural pattern of graben, which was 


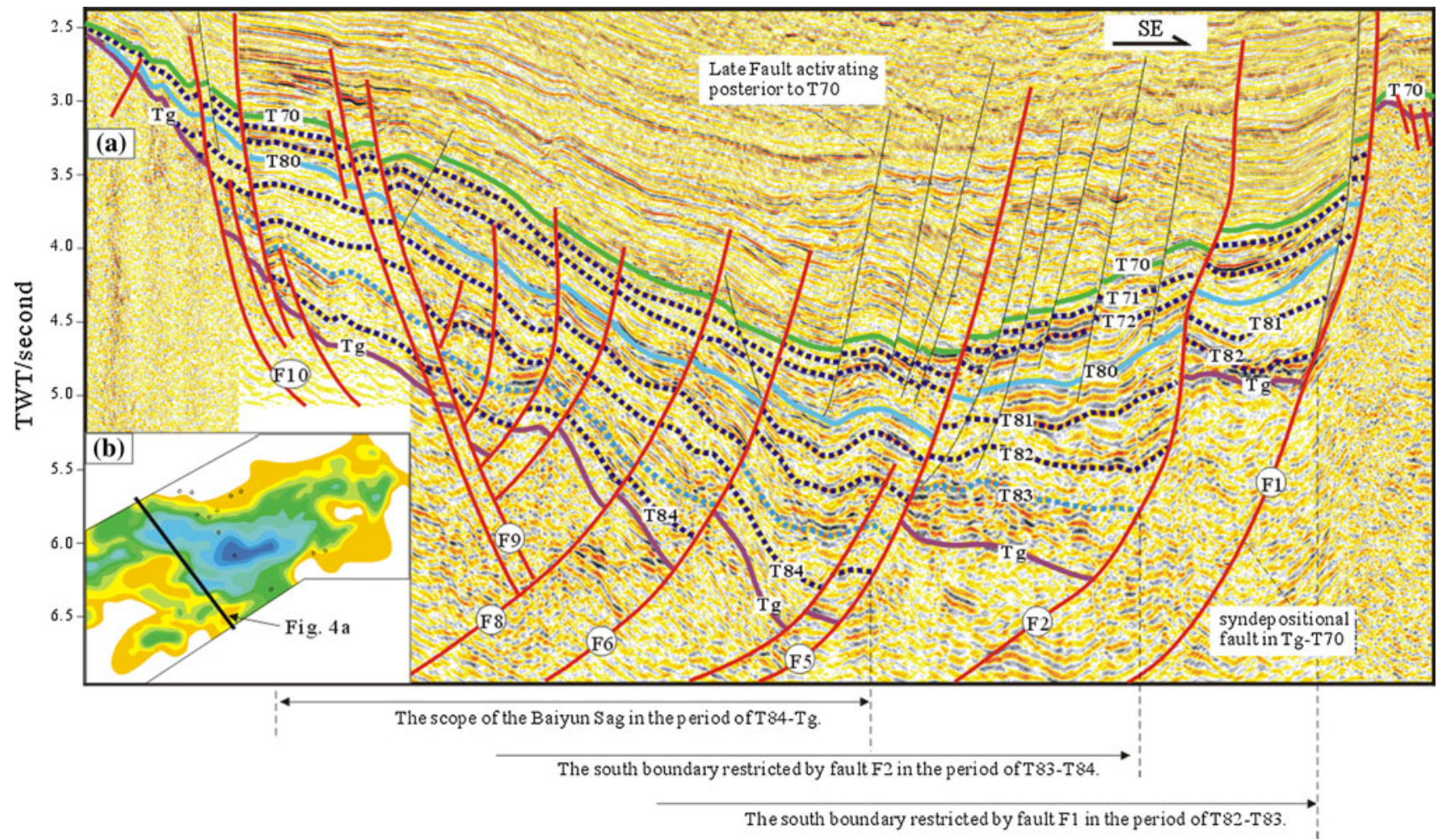

Fig. 4 The much asymmetric structural pattern of copolex graben in the western Baiyun Sag. $T g$ is the bottom surface of Paleogene, T80 and $T 70$ are second-order sequence interfaces, T84-T81, T72 and $T 71$ are third-order sequence interfaces. Sequential faults in $T g-T 70$ (including main faults of $F 1-F 10$ ) were distinguished from late faults activating posterior to $T 70$. From $T g$ to $T 81$, southern boundary fault shifted from $F 5$ to $F 2$, then to $F 1$, which suggested this Sag expanded forward south (see $\mathbf{b}$ for the location of seismic profile in $\mathbf{a}$ )

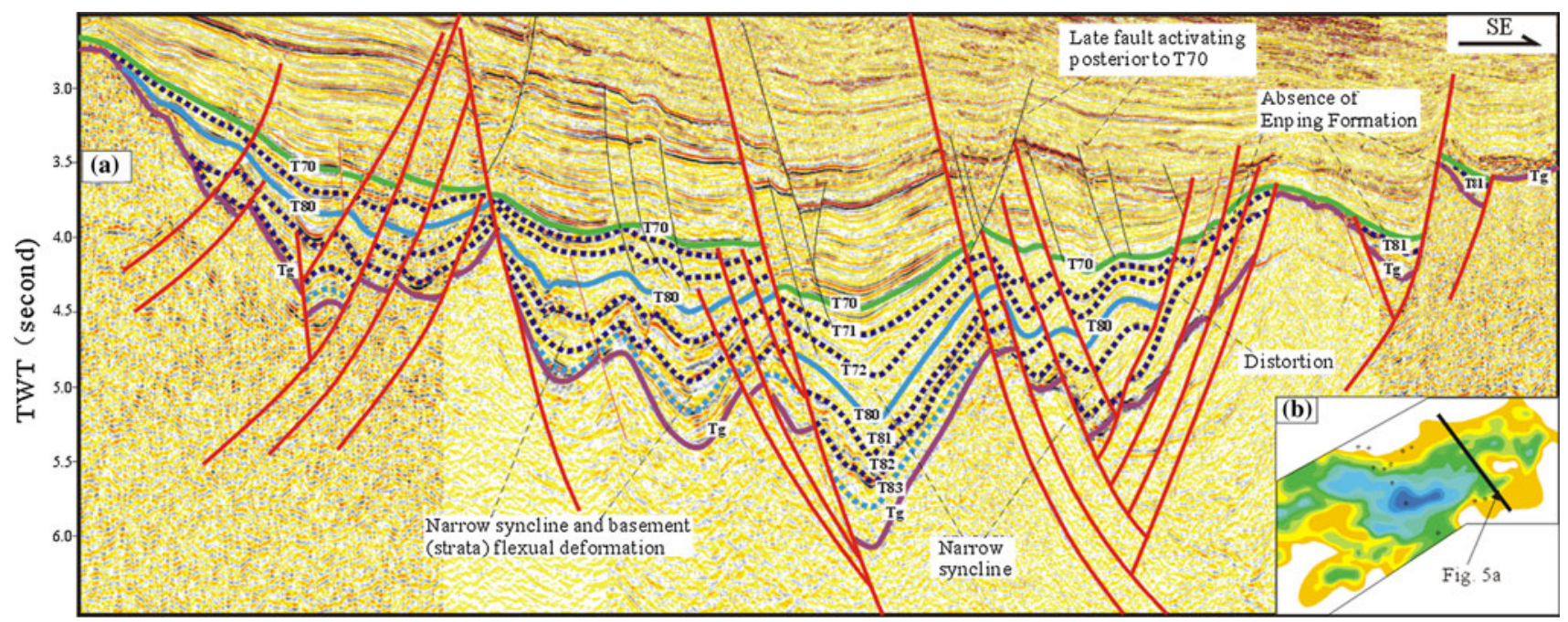

Fig. 5 The structural pattern of the eastern Main Biayun Subsag. Approximate 14 faults with fairly great displacement were identified. The southern mini-sag presents graben pattern (see $\mathbf{b}$ for the location of $\mathbf{a}$ )

comparable to the mini-sag in the southeastern corner of the Main Baiyun Sag. As a whole, the southwestern faults dominantly dipped toward the NNE, whereas most of the northeastern faults dominantly dipped toward SSW. This is to say, the southwestern faults roughly dipped opposite to the northeastern faults. Both of them had played the roles of boundary faults to collectively control the development of the Baiyun Sag, so the subsiding center (with the thickest strata) departed from main faults and located in the middle of the Main Baiyun Subsag, where the main 

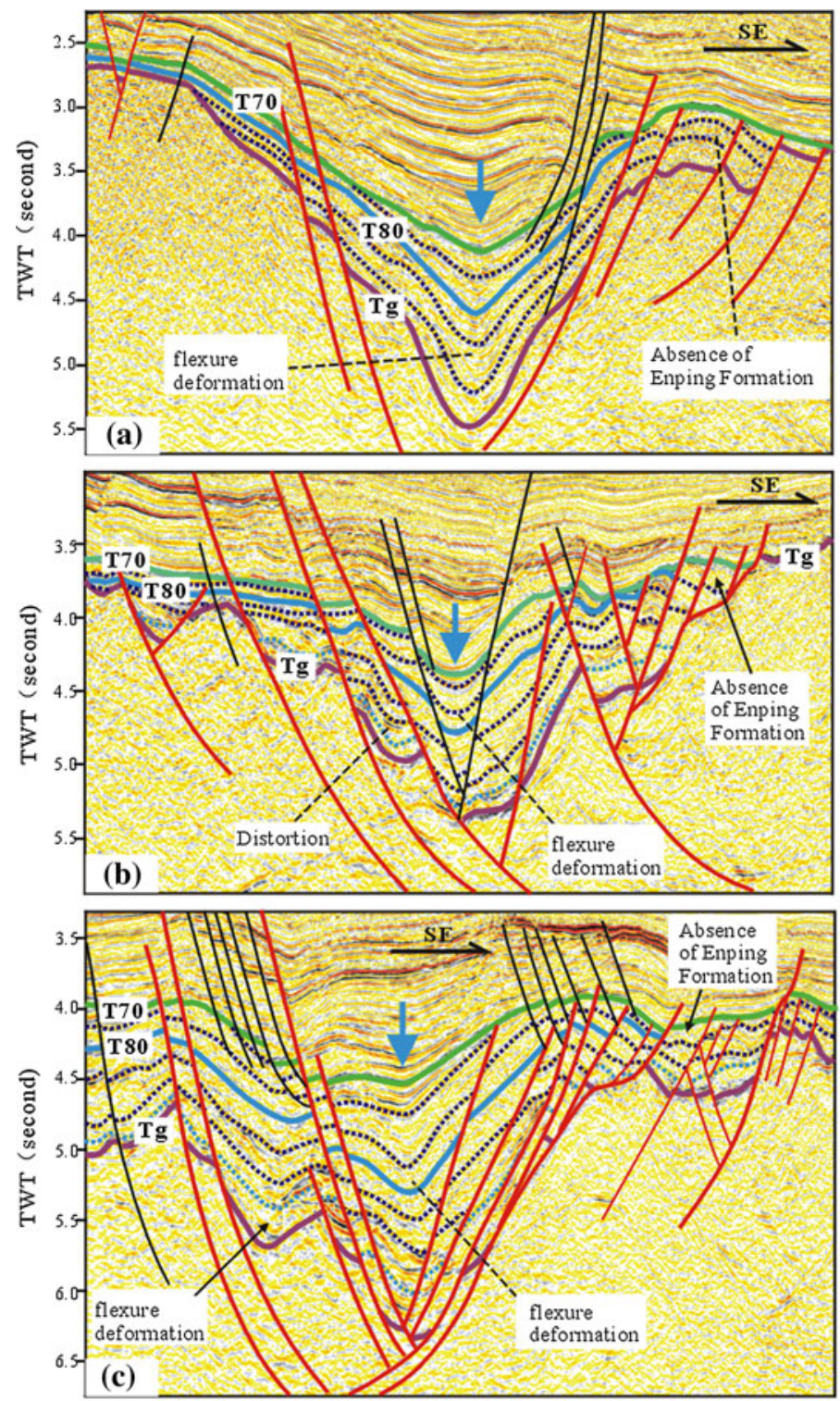
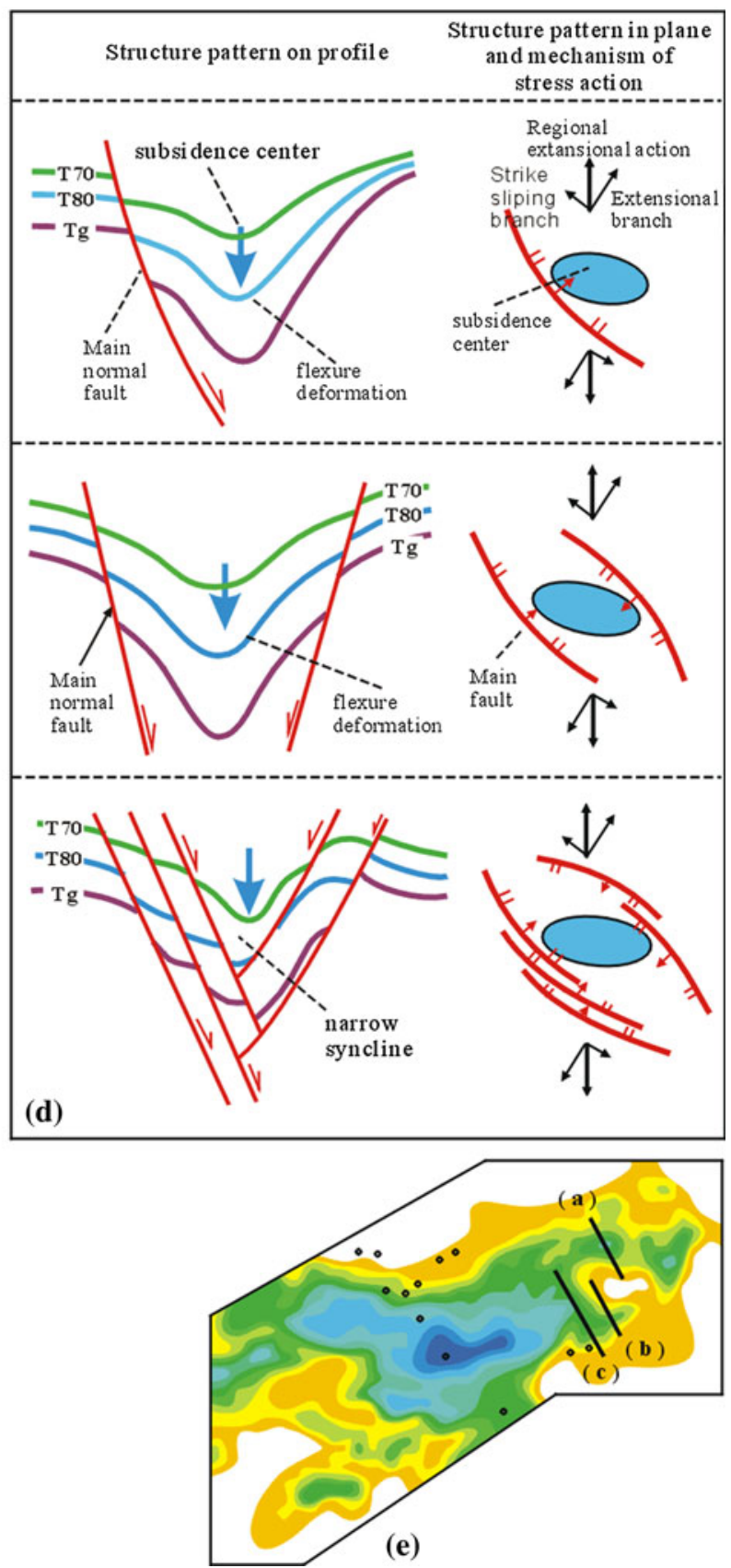

(e)
Fig. 6 Tectonic patterns of narrow syncline in eastern Baiyun Sag. a-c Illustrate narrow synclines on seismic profiles, where the subsidence centers with the thickest strata are deflected to the main

extensional force had exerted (Fig. 2). Finally, abundant en echelon faults, together with boundary faults shifting, indicated left-lateral transtensional tectonism.

Narrow synclines

In the eastern Baiyun Sag, many small-scale narrow minisags, named as "narrow syncline" in this paper, were special in their subsiding centers departing from main faults (Figs. 5, normal faults. In $\mathbf{d}$, three typical tactonic models of narrow syncline are concluded (see $\mathbf{e}$ for the locations of $\mathbf{a}-\mathbf{c}$

6), and were classified as three types (Fig. 6d) as follows: (1) the narrow synclines are of half-graben structure pattern (Fig. 5), (2) Two main faults had developed in the each side of narrow synclines respectively to construct a simple graben structure pattern (Fig. 6a), (3) in the two sides of narrow synclines, seven or eight faults stacked with opposite dips to construct the structure pattern of complex graben (Figs. 5, 6c).

In above types of narrow syncline, subsiding centers weren't distributed adjacent to the main faults, and 

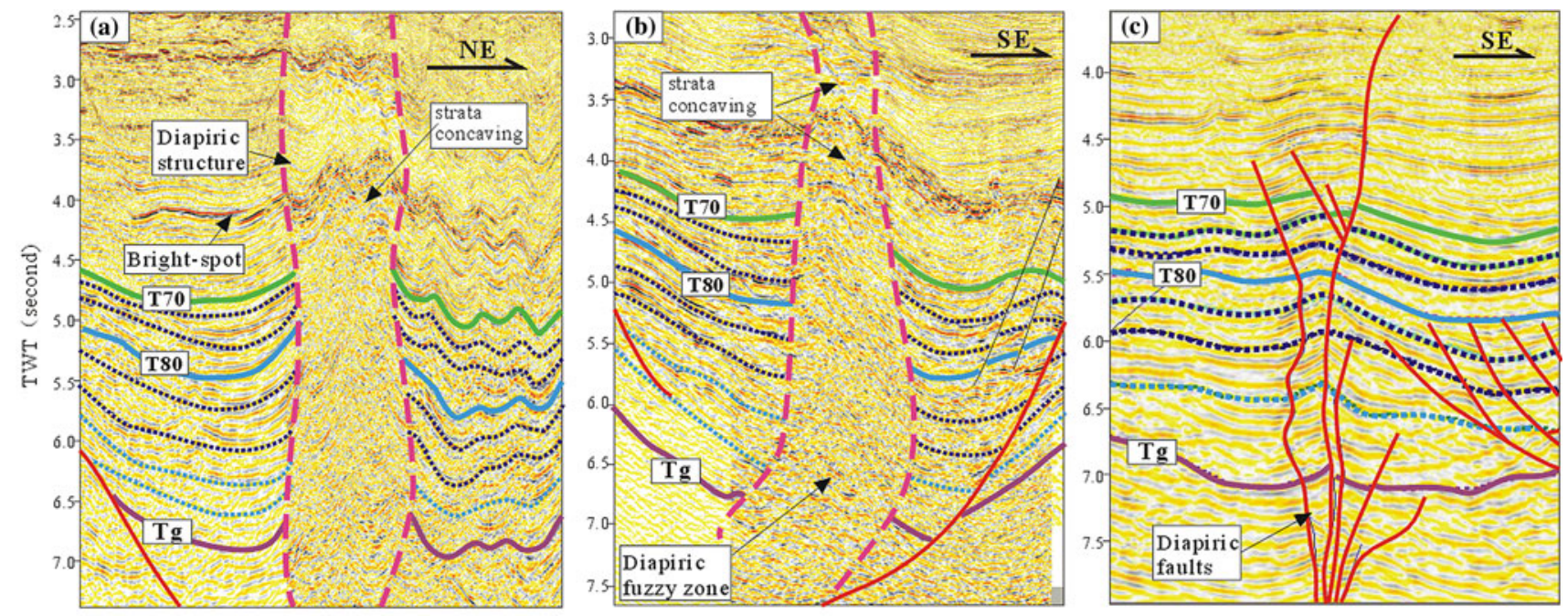

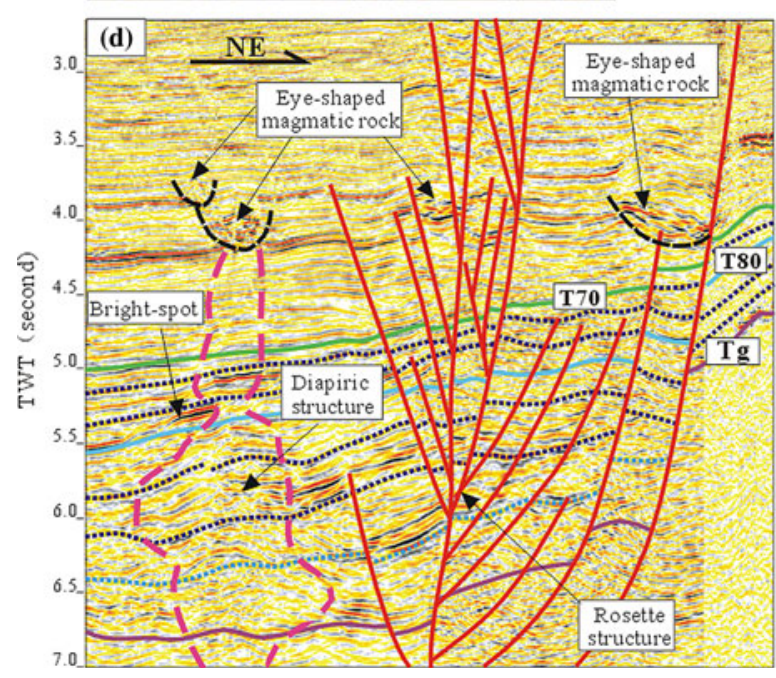

Fig. 7 Diapirs and partially rosette structure in Baiyun Sag. The diapiric structures are shown turtleback-liking arches, weak pierce and fuzzy zones on seismic profiles in $\mathbf{a}, \mathbf{b}, \mathbf{d}$ and faults in $\mathbf{c}$. In the

basement (or strata) flexure sink had occurred. Specially, in some narrow synclines, no main fault was found (Fig. 5). It shouldn't be caused by pure extension, torsional action might be responsible for this basement flexure. Therefore, narrow synclines were regarded as a symbol for transtensional tectionism.

\section{Negative flower structures}

As a kind of reliable evidence of torsional structure, a few small-scale negative flower structures had been identified in the southeast Main Baiyun Subsag. In these flower structures, the faults were of small displacement, almost vertical dip, irregular plane and flower-like assembly. Locally, eyeshaped magmatic rocks on the top of the structures indicate magma intrusion along the faults (Fig. 7d). diapirs, the deep strata were arched, but shallow strata were fallen which was resulted from natural gas injection in $\mathbf{a}$ and $\mathbf{b}$ (see $\mathbf{e}$ for the location of $\mathbf{a}-\mathbf{d}$ )

Fluid diapirs

Typical fluid diapirs had formed in the Baiyun Sag (Wang et al. 2006; Chen et al. 2006). They were mainly distributed along the W-E direction in the center of the Main Baiyun Subsag. The weak and primary diapirs present turtlebacklike shapes (Fig. 7d) and diapiric faults (Fig. 7c). The intense fluid diapirs, named as "gas-chimney", displayed chaotic zones of seismic reflection (Fig. 7a, b), and had pierced basement and Cenozoic strata more than 10,000 m thick in the center of the Main Baiyun Subsag, and is characterized by the deep-seated strata pulling up and shallow strata falling down due to natural gas injection. Discontinuous seismic reflection in these structures and bright-spots along two sides of these structures (Fig. 7a, b, d) indicated the cause of fluid diapir (Xie et al. 1999, 2001). 

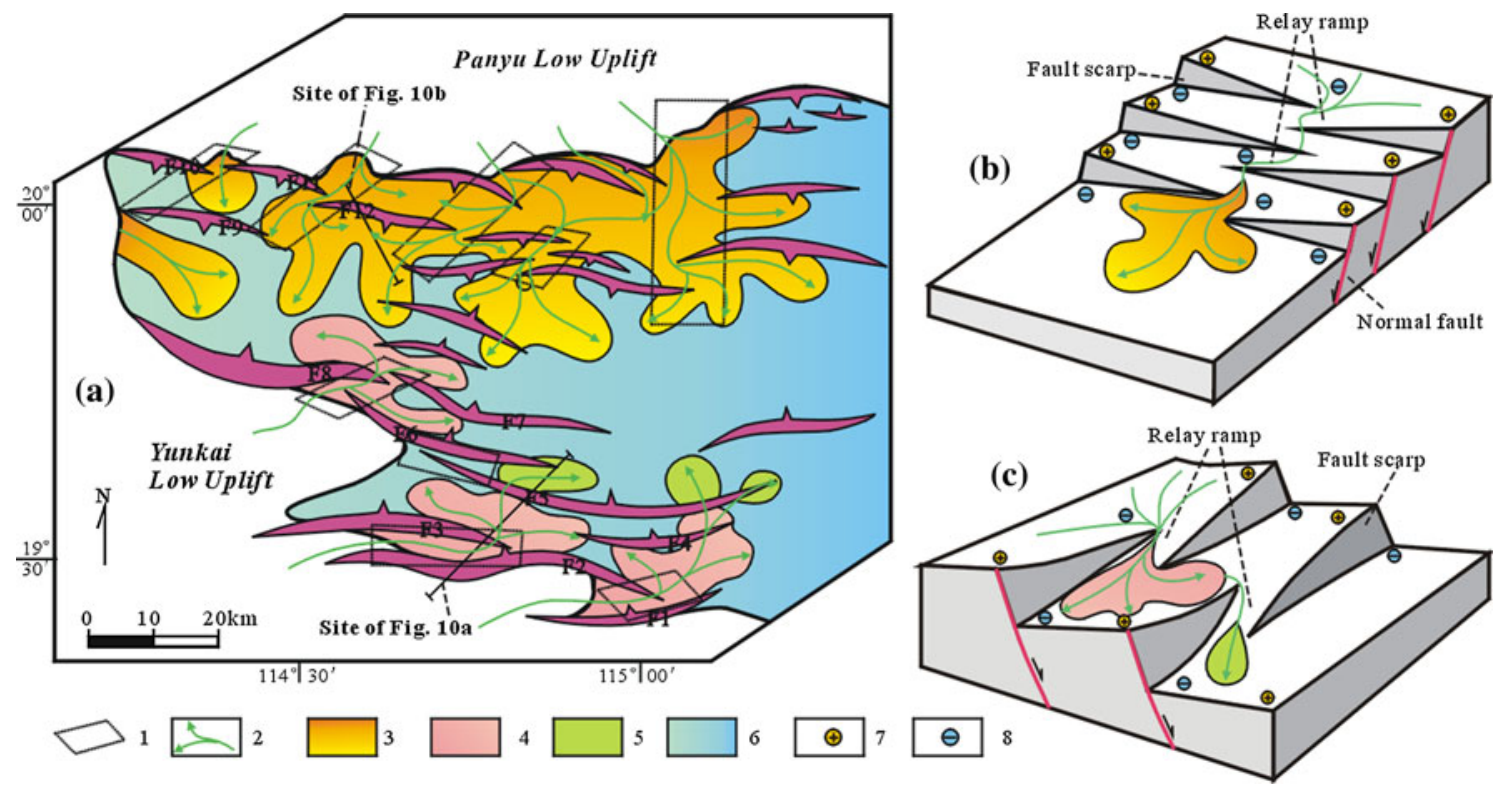

Fig. 8 Faults controls on sandbodies distribution during T83-T84 in western Baiyun Sag. The sedimentary facies distributions in a had derived from seismic facies interpretation. $\mathbf{b}$ and $\mathbf{c}$ The models of relay ramp complex and their controls on sediment transportation in

Well 3 are situated accordant with diapir in Fig. 7a, b, and revealed that the diapir is rich in $\mathrm{CO}_{2}$.

Besides rapid subsidence, high proportion of fine sediments, high geothermal gradient, transtensional and shearing stress fields all played important roles in diapirism (Xie et al. 1999, 2001; Cartwright 1994; Wang and Xie 1998). Diapirs usually benefit from pre-existing cracks and faults formed by transtensional action such as that in Fig. 7c. For example, the large-scale fluid diapirs in the Yinggehai Basin were closely related to the strike-slip movement of Red River faults (Xie et al. 1999; Hao et al. 2001). In the middle of Main Baiyun Subsag, strata with sedimentary facies of deep lacustrine were mud-rich. Furthermore, transtensional tectonism in Paleogene should be responsible for these fluid diapirs although some of them originated much late and kept active till nowadays to form seabed-pits (Wang et al. 2006).

\section{En echelon faults controlling on distribution of sandbodies}

Abundant en echelon faults in the study area had constructed many transfer zones of relay ramps. As an important style of transfer zones, relay ramps are formed by two partially overlapped faults with uniform dips (Scott and Rosendahl 1989; Morley et al. 1990; Morley 2007; McClay et al. 2002). Previous studies had revealed that relay ramps usually acted as ideal entrances of provenance and then forcefully controlled on sandbodies distribution (Faulds and Varga 1998; Wang et al. 2008, 2010). northwest and southwest of Baiyun Sag respectively. 1 Site of relay ramp complex, 2 sediment transportation path, 3 delta facies, 4 fan delta facies, 5 turbidite fan facies, 6 lake facies, 7 highland, 8 lowland

The mechanism for relay ramp's control on sandbodies distribution is that segmental active faults change geomorphology. Corresponding to the intensively active segment of a fault, its hanging wall subsides to be lowland while its footwall is isostatically uplifted to be a highland. As the fault waned till to be stagnant along its strike, the highland at the footwall was gradually fell till to disappear. A relay ramp, where the two faults are weak to stagnant, is a low and gently slope, can collect and conduct drainage into basin. Typical relay ramps had developed in the southwestern and northwestern Baiyun Sag. Associated with en echelon fault belts, two or three relay ramps had usually constituted a complex relay ramps (Fig. 9b, c).

In the development of Wenchang Formation, the Panyu Low Uplift, Yunkai Low Uplift and Southern Uplift Belt were widely exposed to supply abundant sediments, the faults were strongly active, so these complexes of relay ramps had prominently controlled on sandbodies distribution. As shown in Fig. 8a, during T83-T84, four largescale deltas in the northwestern Baiyun Sag distributed in correspondence with four relay ramp complexes. These deltas present seismic facies of sigmoidal progradational reflection, and incised valleys with concave shape and erosional bottom surface indicated the routes of sediment transportation (Fig. 9a). Similarly, three large fan deltas and turbidite fans in the southwestern Baiyun Sag, which present seismic facies of sphenoid progradational reflection and mound-shaped reflection respectively (Fig. 9b), distributed in correspondence to three relay ramp complexes. 

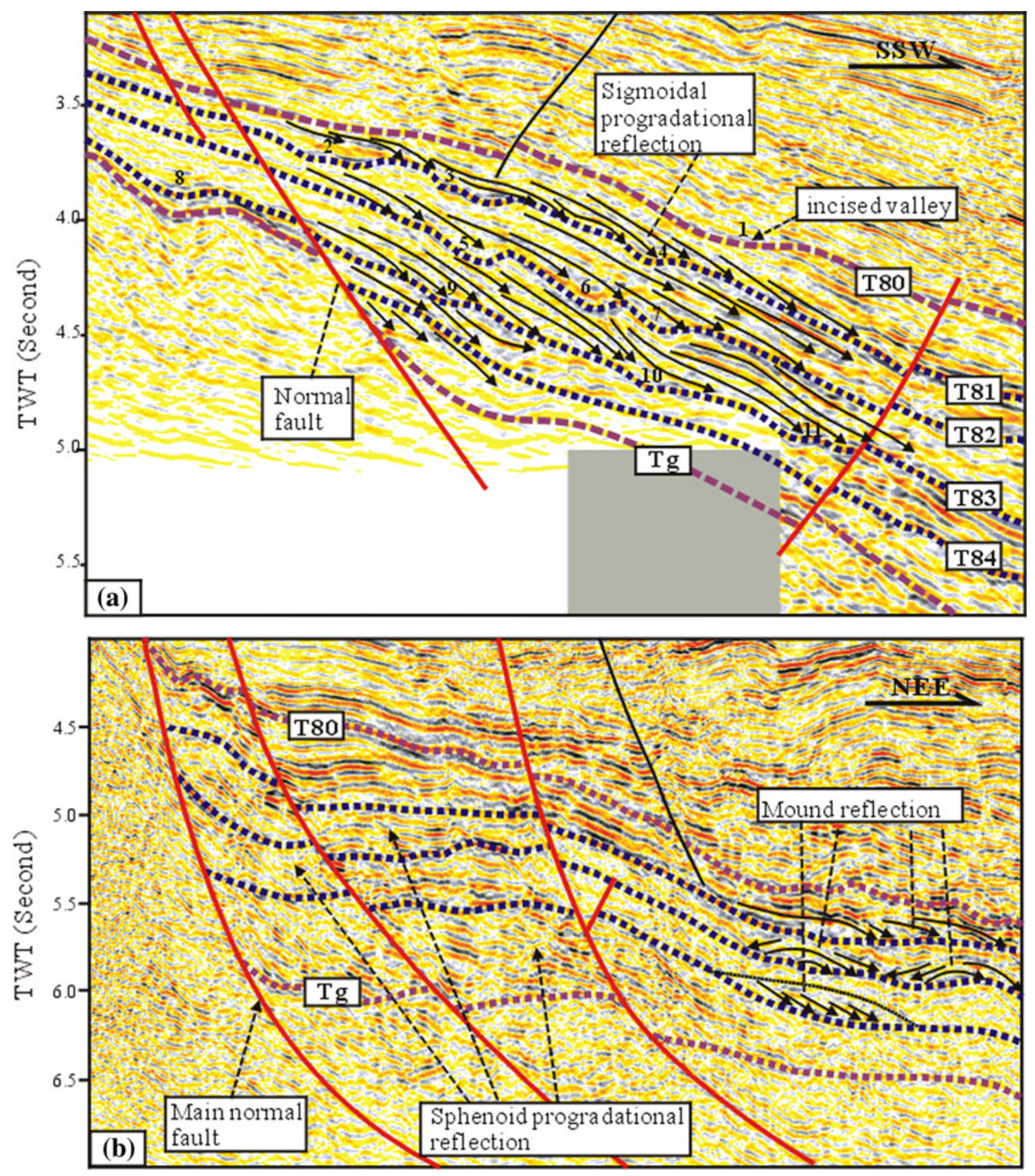

Fig. 9 Several kinds of seismic reflection configuration. a Seimic facies of sigmoidal progradational reflection and incised valley filling at the northwestern Baiyun Sag, and 11 incised valleys (1-11) were identified to indicate the routes of sediment transportation. b The

\section{Discussion}

Due to the subduction zone of western Pacific plate retreated after the Late Cretaceous, back-arc spreading occurred at the southeastern margin of the Eurasia Plate (Zhou et al. 1995), and the Pearl River Mouth Basin came into a rifting evolution period. Zhou et al. (1995) and Chen et al. (2005) emphasized that the India Plate subducting seismic configuration of sphenoid progradational reflection and mound reflection at the southwestern of Baiyun Sag (see Fig. 8a for the profile locations)

towards the Eurasia Plate led to right-lateral transtensional action in the Cenozoic, but this subduction couldn't affect the study area especially in the development of Wenchang Formation because a significant "hard" collision between the India Plate and the Eurasia Plate occurred after late Eocene (Lee and Lawver 1995; Sun et al. 2006).

Analysis of total horizontal gradient of Bouguer gravity anomalies and magnetic anomaly zone, Chen et al. (2005) 
Fig. 10 Major Mesozoic structures of Zhujiang River Mouth basin (after Chen et al. 2005). 1 Sub duction belt, 2 strike-slip fault, 3 volcano island arc, 4 forearc basin
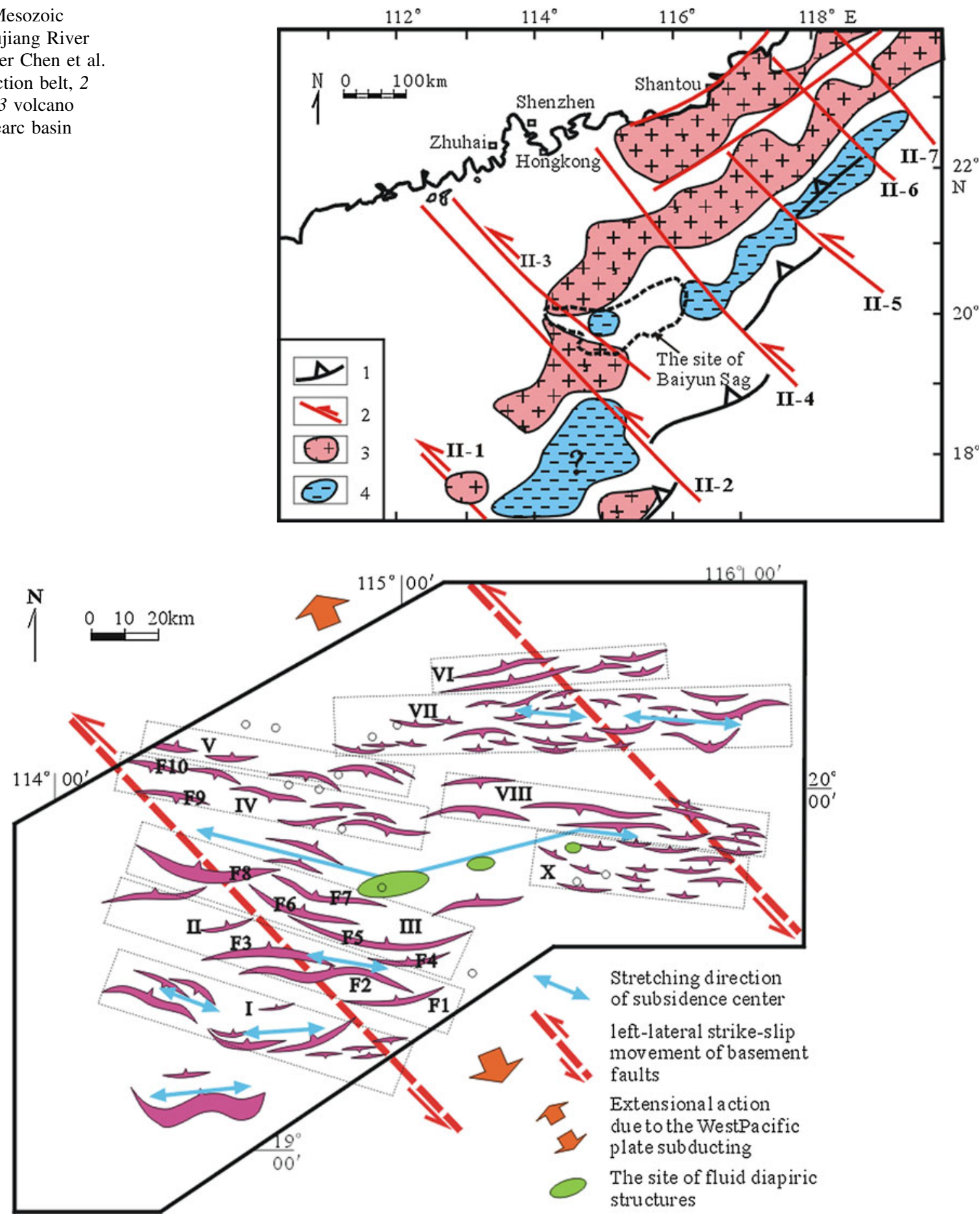

Fig. 11 Sketch map showing the stress action. Nine en echelon faults belts was classified as $I-X$. The subsidence center of the Western Subsag and Main Baiyun Subsag stretched as S-shaped. Fluid diapiric structures beaded distributed along approximately E-W direction

revealed that there were seven large-scale NW-trending basement faults of left-lateral strike-slip at the Pearl River Mouth Basin (Fig. 10). These basement faults, as well as NE-stretching Mesozoic compressive structures such as volcanic island arc and forearc basin, had constituted a leftlateral compressive-shear system, which were thought to result from NW-oriented subduction of western Pacific Plate.

Accompanied by the Cenozoic magmatic action, these NW-trending basement faults were reactivated in Cenozoic, and had controlled the segmented structural framework of Pearl River Mouth Basin in the NEE direction (Fig. 1). Well 

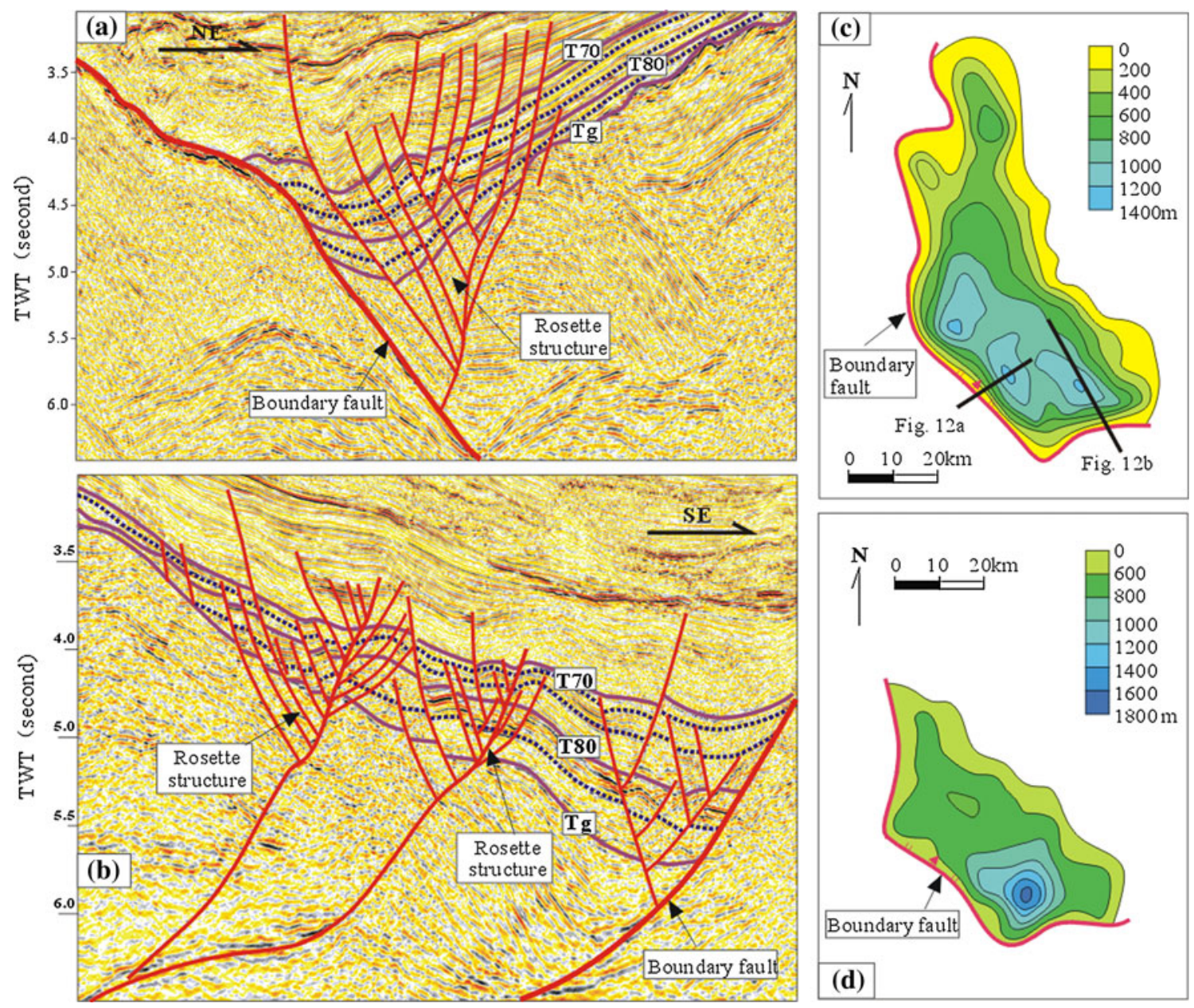

Fig. 12 Negative rosette structures (a, b) and isopach maps of Wenchang (c) and Enping Formation (d) in the Xingning Sag. $\mathbf{c}$ The location of the profiles in $\mathbf{a}$ and $\mathbf{b}$

1 (Fig. 2) incompletely revealed a set of $72.5 \mathrm{~m}$ thick volcanic breccia underlying Enping Formation; Well 2 (Fig. 2) revealed several sets of totally $400 \mathrm{~m}$ thick basalt and andesite (17.1-35.5 Ma), which suggested the fault of II-2 and II-3 intensely active. In middle Eocene to lower Oligocene, regional extensional direction $\left(\mathrm{SE} 150^{\circ}-\mathrm{SE} 170^{\circ}\right)$ was oblique to the strike of basement faults (SE135 ${ }^{\circ}$ or NW315 $)$. Consequently, basement faults of II-2, II-3 and II-4, as well as restriction of rigid basement such as the Yunkai Low Uplift and Eastern Low Uplift, had remarkably performed left-lateral strike-slip movement (Sun et al. 2003, 2005).

Accordingly, the Baiyun Sag had developed above the Mesozoic forearc basin, and was confined by basement faults II-2 and II-4. The southwestern en echelon fault belts situated accordant with II-2 and II-3(Fig. 10). Rationally, a basement fault was speculated to have developed accordant with the northeastern en echelon fault belts. In conclusion, in middle Eocene to early Oligocene Baiyun Sag, strike slip movement of basement faults had induced abundant en echelon faults in capping rocks (Gartrell et al. 2005; Tong et al. 2009), and left- lateral transtensional action was resulted from the Pacific plate subducting toward NW and basement faults' left-lateral strike-slip reactivation (Fig. 11). The subsiding center of the Western Subsag and Main Baiyun Subsag stretched as S-shaped, which was a sign of transitional tectonism. In the middle of Main Baiyun Subsag, the subsiding center, accompanied with beaded fluid diapirs, had chiefly suffered tensional stress to display along approximately $\mathrm{E}-\mathrm{W}$ direction (vertical to direction of regional extensional action).

Differently, the By28 Subsag originated on the Southern Uplift Belt, where the Mesozoic volcanic island arc had developed. It had hardly influenced by basement faults and presented the typical structure pattern of half-graben with main faults vertical to regional extensional direction.

In fact, NW-trending basement faults should be paid more attention. They rather than NEE-trending faults had forcefully controlled the sag's structural pattern in the south of Pearl River Mouth Basin. Another excellent example is from the Xingning Sag (Fig. 1). The Xingning Sag was controlled by a NW-trending boundary fault, and 
presented a half-graben structure. This Sag had gradually extended forward north (Fig. 12c, d), and a few negative flower structures had well developed (Fig. 12a, b), which perfectly indicated left-lateral transtensional action.

\section{Conclusion}

1. The Paleogene Baiyun Sag was distinct from typical half-graben or graben. Two groups of en echelon fault belts with opposite inclinations developed in southwestern and northeastern Baiyun Sag respectively, they had played the role of boundary faults to control the development of Baiyun Sag. The abundant en echelon faults, together with narrow synclines, partial flower structures and fluid diapirs, indicated left-lateral transtensional activities.

2. The term of "narrow syncline" is used to describe a small-scale sub-sag, which was characterized by basement flexure deformation so as to subsiding center departing from boundary faults. The narrow syncline resulted not only from faulted action but also from torsional action. Many narrow synclines had formed in the northeastern Bainyun Sag and were an important mark of transtensional tectonism.

3. Widespread en echelon faults had constructed many composite transfer zones of relay ramps, and had remarkably controlled the sandbody's distributions.

4. The left-lateral transtensional action in the middle Eocene to lower Oligocene Baiyun Sag resulted from both NW-trending basement faults reactivation and the western Pacific Plate subduction.

Significantly, under the transtensional stress field, a large number of normal faults had grown in the middle Eocene to lower Oligocene Baiyun Sag. Most of them remained active and gave rise to many new faults in Neogene (Figs. 3, 4, 5). These faults, together with fluid diapirs, provided paths for vertical migration of hydrocarbon, so the favorite area of oil and gas exploration should coincided with en echelon fault belts.

Open Access This article is distributed under the terms of the Creative Commons Attribution License which permits any use, distribution, and reproduction in any medium, provided the original author(s) and the source are credited.

\section{References}

Cartwright JA (1994) Episodic basin—wide fluid expulsion from geopressured shale sequences in the North Sea basin. Geology 22:447-450

Chen HZ, Wu XJ, Zhou D, Wang WY, Hao HJ (2005) MesoCenozoic faults in Zhujiang River Mouth Basin and their geodynamic background. J Trop Oceanogr 24(2):52-61 (in Chinese with English abstract)
Chen HH, Chen CM, Pang X, Wang JH, Shi WZ (2006) Natural gas sources, migration and accumulation in the shallow water area of the Panyu lower uplift: an insight into the deep water prospects of the Pearl River Mouth Basin, South China Sea. J Geochem Explor 89:47-52

Faulds JE, Varga RJ (1998) The role of accommodation zone and transfer zone in the regional segmentation of extended terrenes. In: Faulds J, Stewart J (eds) Accommodation zones and transfer zones: the regional segmentation of the basin and range provinces. Geology Society of America Special Paper, vol 323, pp 1-45

Gartrell A, Hudson C, Evans B (2005) The influence of basement faults during extension and oblique inversion of the Makassar Straits rift system: insights from analog models. AAPG Bull 89(4):495-506

Hao F, Li ST, Gong ZS (2001) Mechanism of diapirism and episodic fluid injections in the Yinggehai Basin. Sci China (Ser D) 31(6): $471-476$

Huang CJ, Zhou D, Sun Z, Chen CM, Hao HJ (2005) Deep crustal structure of Baiyun Sag, northern South China Sea revealed from deep seismic reflection profile. Chin Sci Bull 50(1):1-8

Lee TY, Lawver LA (1995) Cenozoic plate reconstructions of southeast Asia. Tectonophysics 251:8-138

Liu BJ, Pang X, Yan CZ, Liu J, Lian SY, He M, Shen J (2011) Evolution of the Oligocene-Miocene shelf slope-break zone in the Baiyun deep-water area of the Pearl River Mouth Basin and its significance in oil-gas exploration. Acta Petrol Sin 32(2): 235-242 (in Chinese with English abstract)

McClay KR, Dooley T, Whitehouse P, Mills M (2002) 4-D evolution of rift systems: insights from scaled physical models. AAPG Bull 86(6):935-959

Morley CK (2007) Variations in late Cenozoic_-recent strike slip and oblique-extensional geometries of pre-existing fabrics. J Struct Geol 29(1):36-58

Morley CK, Nelson RA, Patton TL, Munn SG (1990) Transfer zones in the East African rift system and their relevance to hydrocarbon exploration in rift. AAPG Bull 74(8):1234-1253

Pang X, Yang SK, Zhu M, Li JS (2004) Deep-water fan systems and petroleum resources on the northern slope of the South China Sea. Acta Geol Sin 78(3):626-631

Pang X, Chen CM, Shi HS, Shu Y, Shao L, He M, Shen J (2005) Response between relative sea level change and the Pearl River deep-water fan system in the South China Sea. Earth Sci Front 12(3):167-177 (in Chinese with English abstract)

Pang X, Shen J, Yuan LZ, Lian SY, He M, Shu Y (2006) Petroleum prospect in deep-water fan system of the Pearl River in the South China Sea. Acta Petrol Sin 27(3):11-15 (in Chinese with English abstract)

Peng DJ, Chen CM, Pang X, Zhu M, Yang F (2004) Discovery of deep-water fan system in South China Sea. Acta Petrol Sin 25(5):17-23 (in Chinese with English abstract)

Peng DJ, Pang X, Chen CM, Yu S, Ye B, Gan JG, Wu CR, Huang XL (2005) From shallow-water shelf to deep-water slope: the research of deep-water fan systems in South China Sea. Acta Sedimentol Sin 23(1):1-11 (in Chinese with English abstract)

Scott DL, Rosendahl BR (1989) North Viking Graben: an East African prospective. AAPG Bull 73(2):155-165

Sun Z, Zheng ZH, Zhou D, Qiu XL, Li XX (2003) Experimental evidence for the dynamics of the formation of the Yinggehai basin, NW South China Sea. Tectonophysics 372:41-58

Sun Z, Pang X, Zhong ZH, Zhou D, Chen CM, Hao HJ, He M, Huang CJ, Xu HH (2005) Dynamics of Tertiary tectonic evolution of the Baiyun Sag in the Pearl River Mouth Basin. Earth Sci Front 12(4):489-498 (in Chinese with English abstract)

Sun Z, Zhou D, Zhong ZH, Xia B, Qiu XL, Zeng ZX, Jiang JQ (2006) Research on the dynamics of the South China Sea opening: evidence from analogue modeling. Sci China Ser D Earth Sci 49(10):1053-1069 
Tong HM, Meng LJ, Cai DS, Wu YP, Li XS, Liu MQ (2009) Fault formation and evolution in rift basins-sandbox modeling and cognition. Acta Geol Sin 83(6):759-774 (in Chinese with English abstract)

Wang CY, Xie XN (1998) Hydro-fracturing and episodic fluid flow in shale-rich basins: a numerical study. AAPG Bull 82(11):1857-1869

Wang JH, Pang X, Wang CW, He M, Lian SY (2006) Discovery and recognition of the central diapiric zone in Baiyun depression, Pearl River Mouth Basin. Earth Sci J China Univ Geosci 31(2):209-213 (in Chinese with English abstract)

Wang JH, Wang H, Xiao DQ, Pu XG (2008) Transfer zone controlling on sandbodies in extensional structure system: a new solution to predict reservoir. Oil Gas Geol 29(1):19-25 (in Chinese with English abstract)

Wang JH, Wang H, Ren JY, Xiao DQ, Pu XG (2010) A great oblique transition zone in the central Huanghua Depression and its significance for petroleum exploration. Acta Petrol Sin 31(3):355-360 (in Chinese with English abstract)
Xie XN, Li ST, Hu XY, Dong WL, Zhang MX (1999) Conduit system and formation mechanism of heat fluids in diapiric belt of Yinggehai Basin, China. Sci China (Ser D) 29(3):247-256

Xie XN, Li ST, Dong WL, Huang HB (2001) Evidence for episodic expulsion of hot fluids along faults near diapiric structures of the Yinggehai Basin, South China Sea. Mar Pet Geol 18(6):715-728

Yu SM, Shi HS, Mei LF, Shu Y, Wu JY (2009) Analysis of tensesharing characteristics of Huizhou Paleogene fault depression in Pearl River Mouth Basin. Petrol Geol Exp 31(5):485-489

Zhou D, Ru K, Chen HZ (1995) Kinematics of Cenozoic extension on the South China Sea continental margin and it's implications for the tectonic evolution of the region. Tectonophysics 251(1-4):161-167

Zhou D, Wang WY, Wang JL, Pang X, Cai DS, Sun Z (2006) Mesozoic subduction-accretion zone in northeastern South China Sea inferred from geophysical interpretations. Sci China (Ser D) Earth Sci 49(5):471-482 